\title{
Estimation of optimum experimental plot size for taro culture
}

\author{
Willerson Custódio da Silva ${ }^{1^{*}}$ (D) Mário Puiatti ${ }^{2}$ (D) Paulo Roberto Cecon $^{3}$ (iD \\ Leandro Roberto de Macedo $^{4}$ (D) Tocio Sediyama ${ }^{5}$ iD
}

${ }^{1}$ Instituto Federal de Minas Gerais (IFMG), Campus Governador Valadares, 35057-760, Governador Valadares, MG, Brasil. E-mail: willersonsilva@gmail.com. .Corresponding author.

${ }^{2}$ Departamento de Fitotecnia, Universidade Federal de Viçosa (UFV), Viçosa, MG, Brasil.

${ }^{3}$ Departamento de Estatística, Universidade Federal de Viçosa (UFV), Viçosa, MG, Brasil.

${ }^{4}$ Departamento de Economia, Universidade Federal de Juiz de Fora (UFJF), Governador Valadares, MG, Brasil.

${ }^{5}$ Departamento de Fitotecnia, Universidade Federal de Viçosa (UFV), Viçosa, MG, Brasil. In memorian.

ABSTRACT: Taro is a tropical tuberous vegetable that produces cormels of high nutritional and energetic value. In recent years, its cultivation has expanded, creating the need for more research. However, the experimental plot size interferes directly with the precision of the experiment. Literature describes several methods for establishing the optimum experimental plot size. The objective of the current research was to estimate the optimal experimental plot size for taro culture, utilizing the Modified Maximum Curvature Method. The field experiment was conducted in the vegetable garden of the Departamentode Fitotecnia of Universidade Federal de Viçosa, from September 2011 to June 2012, with Japanese taro. Twenty-two rows with 20 plants each were planted, at $1.0 \times 0.3 \mathrm{~m}$ spacing, considering the 20 central rows with 18 plants each as useful area, totaling 360 plants. Each plant corresponded to a basic unit (BU). Once the possible clusters were made, 23 different plot sizes were formed. At harvest, the fresh mass characteristics of large, medium, and marketable cormels were evaluated. The optimum plot sizes were: 8.77 BU for marketable cormels; 14.75 BU for large cormels, and 13.37 BU for medium cormels. Among the plot sizes estimated in this study, the aim was to improve precision of experiments performed with taro, plots formed by $15 \mathrm{BU}$ that corresponded to a $4.5 \mathrm{~m}^{2}$ area are recommended. Key words: Colocasia esculenta, yam, experiment.

Estimativa de tamanho ótimo de parcela experimental para a cultura do taro

RESUMO: O taro é uma hortaliça tuberosa tropical que produz cormelos de elevado valor nutritivo e energético. Nos últimos anos seu cultivo tem-se expandido gerando a necessidade de mais informações da pesquisa. Todavia, na pesquisa científica, o tamanho da parcela experimental interfere diretamente na precisão do experimento. Para determinação do tamanho ótimo de parcela, vários métodos têm sido relatados na literatura. O objetivo deste trabalho foi estimar o tamanho ótimo de parcela experimental para a cultura do taro utilizando o Método da Máxima Curvatura Modificado. O experimento foi conduzido a campo, na horta do Departamento de Fitotecnia da Universidade Federal de Viçosa, no período de setembro/2011 a junho/2012, com taro 'Japonês'. Foram plantadas 22 fileiras com 20 plantas cada, no espaçamento de 1,0 0 0,3 m, considerando-se como área útil as 20 fileiras centrais com 18 plantas cada, totalizando 360 plantas. Cada planta correspondeu a Unidade Básica (UB). Feito os possiveis agrupamentos, formaram-se 23 diferentes tamanhos de parcelas. Na colheita avaliaram-se as características massa fresca dos cormelos grande, médio e comerciáveis. Os tamanhos ótimos de parcelas encontrados foram de: 8,77 UB para os cormelos comerciáveis; 14,75 UB para os cormelos grandes e de 13,37 UB para cormelos médios. Dentre os tamanhos das parcelas estimados neste trabalho, de forma a aumentar a precisão experimental em experimentos realizados com taro, sugere-se adotar parcelas formadas por $15 \mathrm{UB}$, o que corresponde a uma área de $4,5 \mathrm{~m}^{2}$.

Palavras-chave: Colocasia esculenta, inhame, experimentação.

\section{INTRODUCTION}

Taro [Colocasia esculenta (L.) Schott], also known as yam in southeast Brazil (PUIATTI, 2002), is a tuberous vegetable of great economic and social importance, especially in the tropical regions of the planet. According to the Food and Agricultural Organization (FAO, 2017), in terms of volume produced in 2014, taro, with 10, 108, $223 \mathrm{t}$, was the fourth highest tropical tuberous vegetable harvested in the world, coming after cassava (268, $277,743 \mathrm{t})$, sweet potatoes $(106,601,602 \mathrm{t})$, and yam $(68,132,129 \mathrm{t})$.

There is a lack of up-to-date information on taro cultivation and production in Brazil. The states of Minas Gerais, Espírito Santo, and Rio de 
Janeiro are the largest producers, with an average productivity of $15 \mathrm{t} \mathrm{ha}^{-1}$, and Espírito Santo already exports around $35 \%$ of its production to markets in Europe, the United States of America, and Canada (CARMO, 2000). According to CONAB (2017), southeastern Brazil plays a significant rolein the supply of taro to the supply centers of the country. In CEASA-MG (2017), for example, taro was mostly supplied from Espírito Santo and Minas Gerais.

Owing to the growing importance of taro culture in recent years, much research has been conducted on this plant. However, today, the competition for research resources is on the rise. In addition, increase in productivity, as a consequence of high technological evolution and genetic improvement, tends to be of a small magnitude (DONATO et al., 2006). Therefore, the need to define the appropriate size of the experimental unit, with minimal investment and a high degree of research accuracy, is justifiable.

In most studies, the plot size has been defined based on the researcher's experience and, in many cases, this decision has been made indiscriminately, without taking into account factors that can affect the size. From the statistical point of view, this practice is not the best, since, besides the crop, optimal plot size depends on soil heterogeneity, variability among individuals, and the design used.

Since the 1930s, there has been discussion about estimates of optimal plot size for different crops (DONATO et al., 2008). Several methods can be used to estimate the optimal size of the experimental plot, and most of them are based on the use of blank tests, also known as uniformity tests. In these tests, the entire experimental area is planted with a single cultivar, using the same practices of cultivation, without any treatments (VALLEJO \& MENDONZA, 1992; ORTIZ, 1995; VIANA et al., 2002b; HENRIQUES NETO et al., 2004), from which the variance and coefficient of variation for different evaluated plot dimensions are calculated.

Among the research carried out with vegetables, involving methods for estimation of the size and shape of experimental plots, one can mention: Italian pumpkin (MELLO et al., 2004); potatoes (OLIVEIRA \& ESTEFANEL, 1995; OLIVEIRA et al., 2005; STORCK et al., 2005); sweet potatoes (CORDEIRO \& MIRANDA, 1983; VALLEJO \& MENDOZA, 1992); cucumber (LORENTZ et al., 2004), and pepper (LÚCIO et al., 2004; LORENTZ et al., 2012). However, only one study, published by MIYASAKA et al., (2013), investigating the taro, was reported in available literature, carried out in Hawaii.
However, as the plot size varies not just based on the crop, it should be estimated specifically for each location, where environmental conditions may vary from those already determined (OLIVEIRA \& ESTEFANEL, 1995). Therefore, the optimal plot size for the taro crop, under the culture conditions adopted, needs to be determined.

There are several methods in the literature to estimate the appropriate plot size; however, there is disagreement among authors regarding the best method. Among the several methods presented in the literature, the most used has been the Maximum Curvature Method (DONATO et al., 2006), and the Modified Maximum Curvature Method. According to DONATO (2006) and VIANA et al. (2002a), in the Modified Maximum Curvature Method, the algebraic determination of the maximum curvature point $\mathrm{X}$ results in higher precision, since the relationship between the coefficient of variation $(\mathrm{CV})$ and plot size is explained by means of a regression equation; however, it results in values that are not necessarily integers. The Modified Maximum Curvature Method allows the estimation of plot sizes smaller than the other methods, a behavior also observed by other authors (VIANA et al., 2002a; HENRIQUES NETO et al., 2004).

Adequate knowledge of the optimal plot size is essential to increase experimental precision. It must be emphasized that the most appropriate plot size depends on several factors, especially those of a practical nature, such as the nature of treatment, area and resource availability, as well as aspects related to the level of statistical accuracy required for performing tests and estimations (CHAVES, 1985). Thus, determination of the ideal plot size is a practical matter pertinent to experimental planning and is crucial for increasing the accuracy of experiments.

The present research was conducted considering that, in research, the experimental precision is fundamental, and in the case of taro culture, there is scare information about the optimal experimental plot size.

The objective of this paper was to estimate the optimum size of the experimental plot for taro crop using the modified maximum curvature method.

\section{MATERIALS AND METHODS}

The field experiment was conducted in the vegetable garden of the Departamento de Fitotecnia da Universidade Federal de Viçosa (UFV), from September 2011 to June 2012. Viçosa is placed at $650 \mathrm{~m}$ altitude, $20^{\circ} 45^{\prime} 47^{\prime \prime}$ South and 42 $49^{\prime} 13^{\prime \prime}$ 
West. According to Köppen's classification, this area presents a "Cwa" climate (humid subtropical climate), with $1,341 \mathrm{~mm}$ annual precipitation on average, and $21.6{ }^{\circ} \mathrm{C}$ and $14{ }^{\circ} \mathrm{C}$ maximum and minimum temperatures, respectively.

Soil samples from the experimental area, Cambisolic Red-Yellow Acrisol, with a clayey texture and $0-20 \mathrm{~cm}$ depth were removed and submitted to chemical analysis. Samples presented the following results: $\mathrm{pH}$ (water) $=6.4 ; \mathrm{P}=180$ and $\mathrm{K}=102 \mathrm{mg} \mathrm{dm}{ }^{-3} ; \mathrm{Ca}^{2+}=5.0 ; \mathrm{Mg}^{2+}=0.7$ and $\mathrm{Al}^{3+}=0.0$ $\mathrm{cmol}_{\mathrm{c}} \mathrm{dm}^{-3} ; \mathrm{B}=0.7 ; \mathrm{Fe}=188 ; \mathrm{Mn}=104.4 ; \mathrm{Zn}=12$ and $\mathrm{Cu}=3.5 \mathrm{mg} \mathrm{dm}^{-3} ; \mathrm{MO}=2.7 \mathrm{dag} \mathrm{kg}^{-1} ;(\mathrm{H}+\mathrm{Al})=2.48$; $\mathrm{SB}=5.10 ; \mathrm{CTC}_{(\mathrm{t})}=9.05$ and $\mathrm{CTC}_{(\mathrm{T})}=8.11 \mathrm{cmol}_{\mathrm{c}} \mathrm{dm}^{-3}$; $\mathrm{V}=73 \%$ and $\mathrm{P}$-rem $=29.9 \mathrm{mg} \mathrm{L}^{-1}$.

The experiment consisted of a blank test, also known as a uniformity assay. In this test, the whole area was cultivated with taro [Colocasia esculenta (L.) Schott], Japanese variety (BGH 5925), subjecting the plants to identical cultivation practices. Cormels with $60 \mathrm{~g}$ mean mass, obtained from the UFV Germplasm Bank of Vegetables (BGH/UFV), were used as seedlings. Based on the results of the chemical and physical soil analysis and following the recommendations for the use of correctives and fertilizers in Minas Gerais ( $5^{\text {th }}$ version) (RIBEIRO et al., 1999), neither liming nor fertilization was necessary. Sixty days after planting, top-dressing was carried out by applying $5 \mathrm{~g}$ of urea per plant.

After plowing and grading the soil, grooves were dug at $0.12 \mathrm{~m}$ depth, spaced $1.0 \mathrm{~m}$, and the seedlings arranged within the grooves, spaced at 0.3 $\mathrm{m}$, forming 22 rows with 20 plants each, totaling 440 plants and $132 \mathrm{~m}^{2}$ area. The 20 central rows with 18 plants each were considered as useful area, totaling 360 plants and $108 \mathrm{~m}^{2}$ useful area. Each plant was considered as a basic unit (BU), occupying a $0.3 \mathrm{~m}^{2}$ area $(1.0 \times 0.3 \mathrm{~m})$.

Each plant was properly identified by its position in the row and column, as a means of simulating plots with different shapes and sizes. Thus, from the blank assay map, it is possible to group the 360 BUs, leading to 33 plot shapes, since we noted that rows $\times$ plants $(\mathrm{r} \times \mathrm{p})$ dimensions have the same size as plots of plants $\times$ rows $(p \times r)$ dimensions. Therefore, out of the 33 parcel forms, 23 distinct modes were observed, which were: $\mathrm{x}=1,2,3,4,5$, $6,8,9,10,12,15,18,20,24,30,36,40,45,60,72$, 90,120 , and 180 . In this way, the area was divided into small plots where the production was separately measured, in such a way that the yield of neighboring plots could be taken together to form plots of different sizes, in accordance with STORCK et al. (2005).
During the growing period, the area was kept free of weeds by manual weeding and an adequate moisture content was maintained with conventional sprinkler irrigation whenever necessary. Spraying with agrochemicals was not conducted, because of the non-occurrence of pests or phytopathogens.

After nine months of this cycle, with the plants at the point of harvest, plant-to-plant harvesting was carried out. The cormels were separated and classified into large, medium, small, and marketable (sum of the large, medium, and small classes). Each kind of cormel was weighed in order to obtain the respective masses of the fresh plant matter.

The modified maximum Curvature Method proposed by LESSMAN \& ATKINS (1963) was used to determine the optimal plot size. This method involves algebraically determining the point with the maximum curvature in the curve that relates the CV to the plot size. According to MEIER \& LESSMAN (1971), this relation between CV and plot size can be estimated by the general equation $\mathrm{Y}=\mathrm{aX}^{\mathrm{b}}$, where $\mathrm{Y}$ represents the variability index and $\mathrm{X}$ is the corresponding plot size in the BUs. In this study, the function $\mathrm{CV}=\mathrm{aX}^{\mathrm{b}}$ was used, and the value corresponding to the point of maximum curvature for this function was estimated by the following formula (MEIER \& LESSMAN, 1971), adopting the symmetric of $b$ in the calculation procedure (CHAVES, 1985):

$$
X_{0}=\left[\frac{a^{2} b^{2}(2 b+1)}{(b+2)}\right]^{\frac{1}{(2 b+2)}}
$$

Where: $\mathrm{X}_{0}$ is the value of the abscissa corresponding to the point of maximum curvature, and $a, b$ are model parameters.

\section{RESULTS AND DISCUSSION}

The productivity of large, medium, small, and marketable cormels were $8.4 ; 10.0 ; 9.4$ and 28.0 tha ${ }^{1}$, respectively. The sum of the classes of large, medium, and small cormels was considered as marketable. These values are significantly above the productivity reported in the literature for Brazilian conditions, indicating that there were no restrictions on the development and growth of plants during cultivation.

It can be seen from figures 1, 2, and 3 that the $\mathrm{CV}$ is inversely proportional to plot size; that is, as the plot size is increased, the CV decreases. The $\mathrm{CV}$ of the large cormels weight ranged from 4.72 to $114.53 \%$; that of medium cormels, from 2.01 to $69.54 \%$; and that of marketable cormels, from 0.76 to $46.30 \%$. This small variation in marketable cormels 


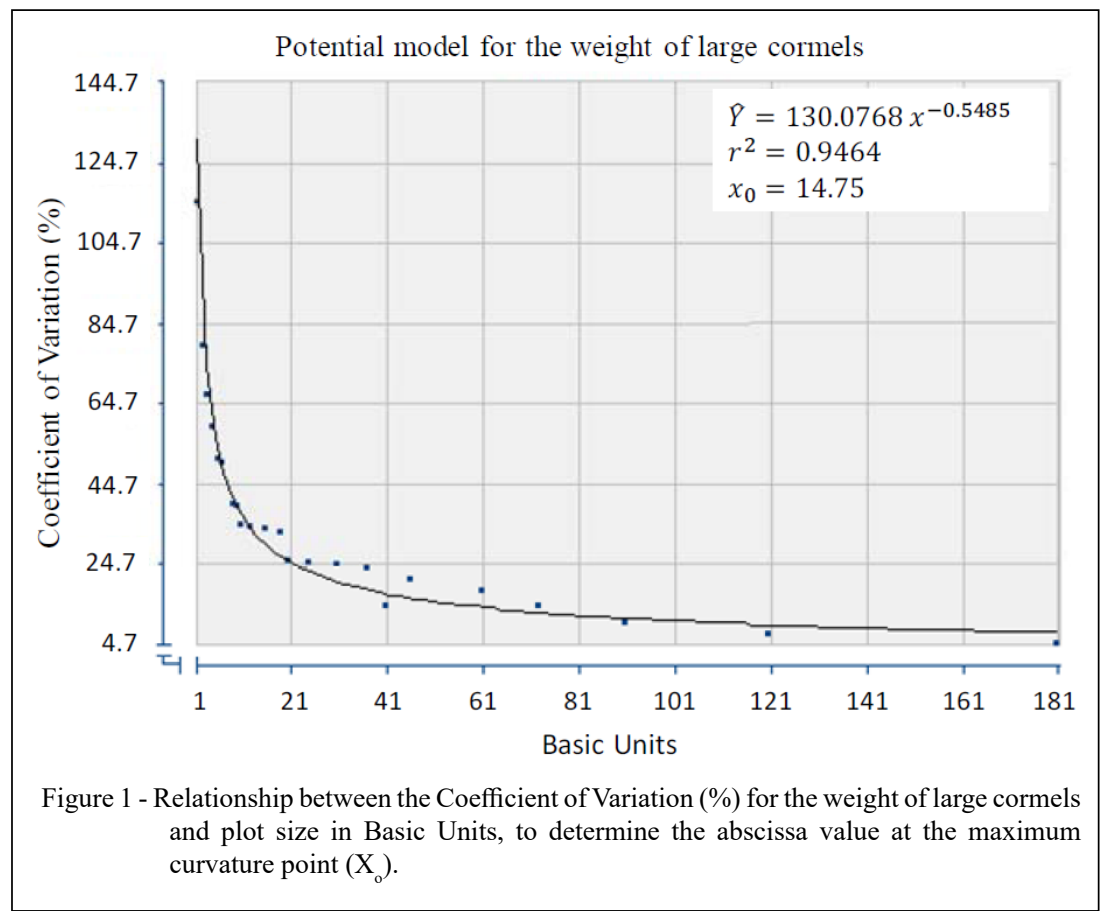

may be because of the fact that this class comprised of large, medium, and small cormels. Therefore, many of the evaluated plants did not always produce all these classes of cormels.
According to the maximum curvature modified method, the estimated optimum plot sizes were 14.75 BU for large cormels, 13.37 BU for medium ones, and 9.0 BU for marketable cormels.

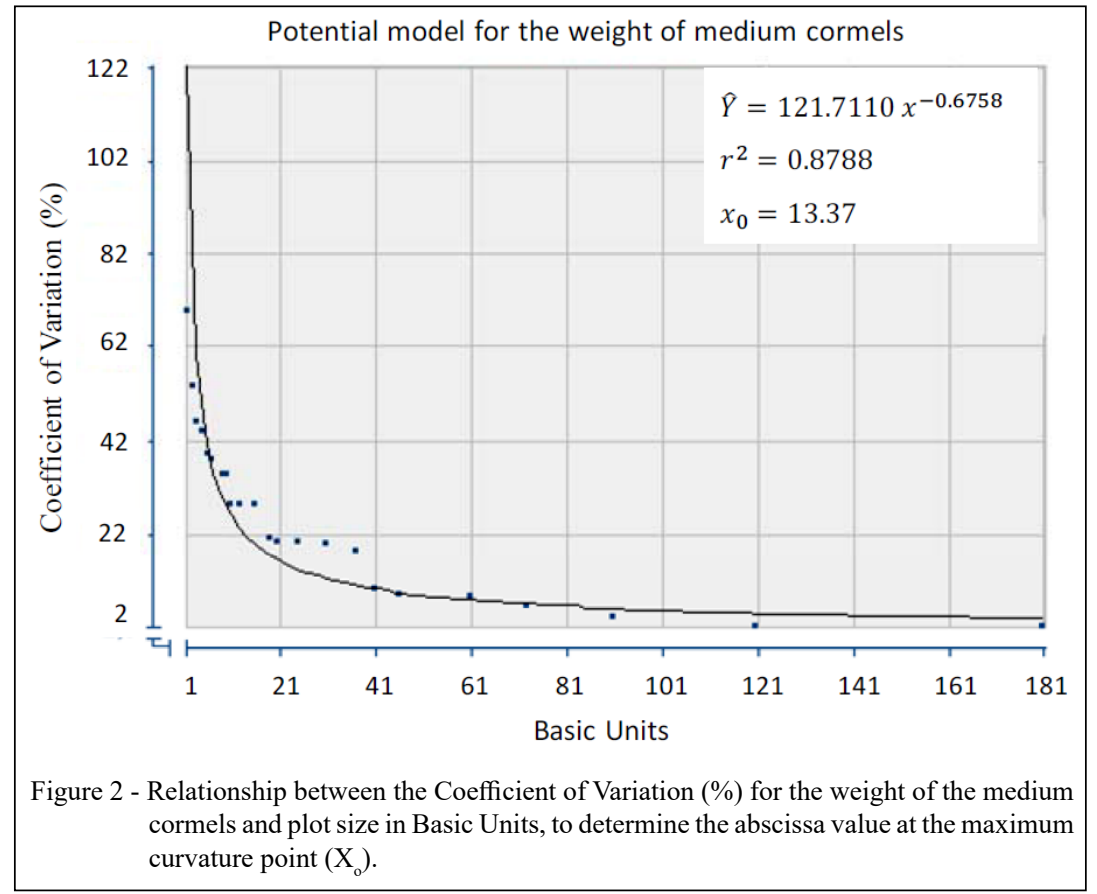

Ciência Rural, v.49, n.5, 2019. 


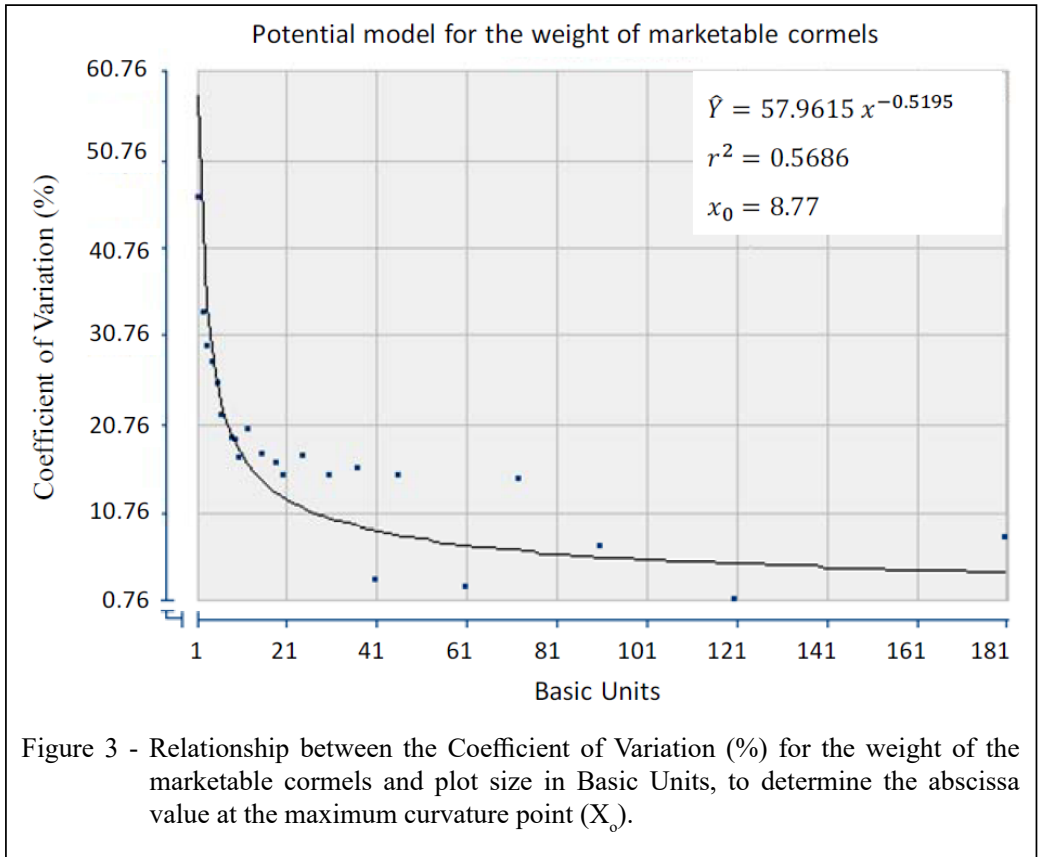

These sizes are not easily identified visually, as we can observe in figures 1,2 , and 3 . This problem was also reported by VIANA et al (2002b), while determining the plot size in experiments with cassava.

Thus, the estimated size of plots for the taro crop is approximately $15 \mathrm{BU}$, based on the large cormels, which correspond to a $4.5 \mathrm{~m}^{2}$ area. This value is lower than that reported by MIYASAKA et. al (2013) while determining the optimal size of the taro plot, in tests conducted under flooded culture and in highland cultures in Hawaii, where they found the optimal size of 21 plants $\left(5.7 \mathrm{~m}^{2}\right)$ for the flooded trial and 18 plants $\left(4.9 \mathrm{~m}^{2}\right)$ for the upland test, using the Maximum Curvature Method. However, this difference may be due to different climatic conditions, as mentioned earlier.

Considering that, in experiments with this crop, the determination of the number of plants per plot has been made empirically, based only on the researcher's experience, the information presented in our study will be important in guiding future research aimed to combine the different factors in experimental design to increase the precision of experiments performed with taro.

\section{CONCLUSION}

Under the conditions described in this experiment, it is suggested that the estimated size of the experimental plot for the taro crop is approximately $15 \mathrm{BU}$, corresponding to a $4.5 \mathrm{~m}^{2}$ area.

\section{ACKNOWLEDGEMENTS}

We acknowledge Conselho Nacional de Desenvolvimento Científico e Tecnológico (CNPq) (process 470392/2012-6) and Fundação de Amparo à Pesquisa do Estado de Minas Gerais (FAPEMIG) (PPM-00146-14) for supporting this research.

\section{DECLARATION OF CONFLICT OF INTERESTS}

The authors declare no conflict of interest. The founding sponsors had no role in the design of the study; in the collection, analyses, or interpretation of data; in the writing of the manuscript, and in the decision to publish the results.

\section{AUTHORS' CONTRIBUTIONS}

The authors contributed equally to the manuscript.

\section{REFERENCES}

CEASA-MG. 2017. Available from: <http://minas.ceasa.mg.gov. br/detec/oferta_preco/oferta_medio_prd/ofertas_medio_prd.php $>$. Accessed: Apr. 17, 2017.

CHAVES L.J. Tamanho da parcela para seleção de progênies de milho (Zeamays L.). 1985. 148f. Thesis (PhD in Genetics and Plant Breeding) - Escola Superior de Agricultura Luiz de Queiroz, University of São Paulo, Piracicaba, 1985.

Ciência Rural, v.49, n.5, 2019. 
CONAB. COMPANHIA NACIONAL DE ABASTECIMENTO. Programa de modernização do mercado brasileiro hortigranjeiros- PROHORTE. 2017. Available from: <http:// www3.ceasa.gov.br/prohortweb>. Accessed: Apr. 17, 2017.

CORDEIRO C.M.T. et al. Plot size and experimental efficiency in sweet potato using the power of test. Pesquisa Agropecuária Brasileira, Brasília, v.18, p.707-713, 1983. Available from: $<$ http:// seer.sct.embrapa.br/index.php/pab/article/view/15347/9212>. Accessed: Oct. 17, 2012.

DONATO, S.L.R. et al. Behavior of banana varieties and hybrids (musa spp.), in two production cycle in the Southwest of bahia state. Revista Brasileira de Fruticultura, v.28, p.139-144, 2006. Available from: $<$ http://www.scielo.br/scielo.php?script=sci_artte xt\&pid=S0100-29452006000100039>. Accessed: Dec. 12, 2013. doi: $10.1590 / \mathrm{S} 0100-29452006000100039$.

DONATO, S.L.R. et al. Estimates of plot size for the evaluation of phenotipics descriptors in banana.Pesquisa Agropecuária Brasileira, v.43, p.957-969, 2008. Available from: <http:// www.scielo.br/scielo.php?script $=$ sci abstract\&pid $=$ S0100204X2008000800003>. Accessed: Dec. 12, 2013. doi: 10.1590/ S0100-204X2008000800003.

FAO. 2017. FAO statistical database. Available from: <http:// www.fao.org/>. Accessed: Apr. 17, 2017.

HENRIQUES NETO D. et al. Plot size in experiments with wheat irrigated under no-tillage and conventional tillage. Pesquisa Agropecuária Brasileira, v.39, p.517-524, 2004. Available from: $<$ http://www.scielo.br/scielo.php?script=sci_arttext\&pid=S0100204X2004000600001>. Accessed: Nov. 07, 2013. doi: 10.1590/ S0100-204X2004000600001.

LESSMAN K.J. et al. Optimum plot size and relative efficiency of lattice designs for grain sorghum yield tests. Crop Science, v.3, n.5, p.477-481, 1963. Available from: $<$ https://dl.sciencesocieties. org/publications/cs/abstracts/3/6/CS0030060477?access $=0$ \&view $=$ pdf $>$. Accessed: Nov. 07, 2013.

LORENTZ L.H. Temporal variation of sample size to greenhouse experiments. Ciência Rural, Santa Maria, v.34, n.4, p.1043-1049, 2004. Available from: $<$ http://www.scielo.br/scielo.php?script $=$ sci arttext\&pid=S0103-84782004000400012>. Accessed: Nov. 10, 2013. doi: 10.1590/S0103-84782004000400012.

LORENTZ, L.H. et al. Proposal method for plot size estimation in crops. Revista Ceres, Viçosa, v.59, n.6, p.772-780, 2012. Available from: $<$ http://www.scielo.br/scielo.php?script $=$ sci arttext\&pid=S0034-737X2012000600006 $>$. Accessed: Nov. 10, 2013. doi: 10.1590/S0034-737X2012000600006.

LÚCIO A.D. et al. Estimate of parameters for the planning of experiments with the culture of the green pepper in restricted area. Horticultura Brasileira, Brasília, v.22, n.4, p.766-770, 2004. Available from: <http://www.scielo.br/scielo.php?script=sci artte xt\&pid=S0102-05362004000400020 > . Accessed: Sep. 05, 2013. doi: $10.1590 / \mathrm{S} 0102-05362004000400020$.

MELLO R.M. Size and form of plots for the culture of the Italian pumpkin in plastic greenhouse. Scientia Agricola. Piracicaba. v.61, n.4, p.457-461, 2004. Available from: <http://www.scielo.br/ scielo.php?script $=$ sci_arttext\&pid=S0103-90162004000400017 $>$. Accessed:Sep. 05,2013. doi: 10.1590/S0103-90162004000400017.
MIYASAKA S.C. et al. Optimum plot size for field trials of taro (Colocasia esculenta). HortScience, v.48, n.4, p.435-443, 2013. Available from: <https://journals.ashs.org/hortsci/view/journals/ hortsci/48/4/article-p435.xml>. Accessed: Sep. 22, 2013. doi: 10.21273/HORTSCI.48.4.435

MEIER V.D. et al.Estimation of Optimum Field Plot Shape and Size for Testing Yield in CrambeabyssinicaHochst. Crop Science, Madison, v.11, n.3, p.648-650, 1971. Available from: $<$ https://dl.sciencesocieties.org/publications/cs/abstracts/11/5/ CS0110050648>. Accessed: Oct. 07, 2013. doi: 10.2135/cropsci19 71.0011183X001100050013x

OLIVEIRA P.H.et al. Optimal size and shape of potato plots in experiments to evaluate potato yields. Ciência Rural, Santa Maria, v.25, n.2, p.205-208, 1995. Available from: $<$ http://www.scielo.br/scielo.php? script=sci_abstract\&pid $=$ S0103-84781995000200004 $>$. Accessed: Oct. 07, 2013. doi: 10.1590/S0103-84781995000200004.

OLIVEIRA S.J.R. et al. Plot size and experimental unit relationship in exploratory experiments. Scientia Agricola, Piracicaba, v.62, n.6, p.585-589, 2005. Available from: $<$ http://www.scielo.br/scielo.php?script=sci_arttext\&pid $=$ S0103-90162005000600012 $>$. Accessed: Oct. 05, 2013. doi: $10.1590 / \mathrm{S} 0103-90162005000600012$.

ORTIZ R. Plot techniques for assessment of bunch weight in banana trials under two systems of crop management. Agronomy journal, Madison, v.87, n.1, p.63-69, 1995. Available from: $<$ https://dl.sciencesocieties.org/publications/aj/abstracts/87/1/ AJ0870010063>. Accessed: Sep. 22, 2013. doi: 10.2134/ agronj1995.00021962008700010011x.

PUIATTI M. Manejo da cultura do taro. In: CARMO CAS. (Ed.). Inhame e taro: sistema de produção familiar. Vitoria, ES: Incaper, 2002, p.203-252.

RIBEIRO, A.C.et al. Recomendações para uso de corretivos e fertilizantes em Minas Gerais - $5^{\text {a }}$ Aproximação. Viçosa: CFSEMG, 1999. 322p.

STORCK L. et al. Length and width of the optimal experimental plot size in potato. Ciência Rural, Santa Maria, v.35, n.5, p.1043-1048, 2005. Available from: $<$ http://www.scielo.br/scielo.php?script $=$ sci abstract\&pid $=$ S0103-84782005000500009 $>$. Accessed: Sep. 06, 2013. doi: $10.1590 / \mathrm{S} 0103-84782005000500009$.

VALLEJO R.L. et al. Plot technique studies on sweetpotato yield trials. Jornal of American Society for Horticultural Science. Alexandria, v.117, n.3, p.508-511, 1992. Available from: $<$ https:// journals.ashs.org/jashs/abstract/journals/jashs/117/3/article-p508. xml>. Accessed: Sep. 01, 2013. doi: 10.21273/JASHS.117.3.508.

VIANA, A.E.S. et al. Estimation of optimum plot size in field experiments with amatto. Bragantia, Campinas, v.61, n.2, p.181-185, 2002a. Available from: <http://www.scielo.br/scielo. php?script $=$ sci_arttext\&pid=S0006-87052002000200011>. Accessed:Feb. 10,2014. doi: 10.1590/S0006-87052002000200011.

VIANA A.E.S.; et al. Estimates of plot sizes in experiments with cassava.Horticultura Brasileira,Brasília, v.20,n.1,p.58-63,2002b. Available from: $<\mathrm{http}: / / \mathrm{www}$. scielo.br/scielo.php?script $=\mathrm{sci}$ artte xt\&pid=S0102-05362002000100011>. Accessed: Feb. 10, 2014. doi: $10.1590 /$ S0102-05362002000100011. 